\title{
Evaluating growth and intrinsic water-use efficiency in hardwood and conifer mixed plantations
}

\author{
Tiziana Gentilesca ${ }^{1}(0) \cdot$ Giovanna Battipaglia $^{2} \cdot$ Marco Borghetti $^{1} \cdot$ Michele Colangelo $^{1,3} \cdot$ Simona Altieri $^{2}$. \\ Agostino M. S. Ferrara ${ }^{1} \cdot$ Antonio Lapolla $^{1} \cdot$ Angelo Rita $^{1,4} \cdot$ Francesco Ripullone $^{1}$
}

Received: 22 September 2020 / Accepted: 17 March 2021 / Published online: 29 March 2021

(c) The Author(s) 2021

\begin{abstract}
Key message Juglans, Fraxinus, Quercus and Pinus species seem to better maximize the carbon-water ratio providing useful indications on species selection for forestry plantations in areas with increasing drought risk.

Abstract Maximizing carbon sequestration for a given water budget is extremely important in the contest of climate change in the Mediterranean region, which is characterized by increasing temperatures and rising water stress. This issue is fundamental for plantation stands, where limited water availability during the growing season reduces $\mathrm{CO}_{2}$ assimilation and, consequently, tree growth. In this study, the main objective was to investigate the performances in terms of carbon-water balance of conifer (Pinus halepensis and Cupressus sempervirens) and hardwood (Quercus robur, Juglans regia, Fraxinus excelsior and Populus spp.) mixed plantations. To this aim, we used carbon isotope signatures to evaluate the intrinsic wateruse efficiency $(i W U E)$ and the species-specific relationship between basal area increments $(B A I)$ and $i W U E$. At the species level, the highest $i W U E$ values corresponded to the lowest carbon accumulation in terms of $B A I$, for water-saving species such as Cupressus. Conversely, Populus had the lowest $i W U E$ and the highest BAI accumulation. Juglans, Fraxinus, and Pinus showed the most balanced ratio between BAI and $i W U E$. Overall, no clear correlation of $i W U E$ and $B A I$ was evident within all species, except for Populus and Cupressus. Considering projected aridification and increased temperatures that will negatively impact the growth, our data suggest that Pinus, for conifers, and Quercus, Juglans, Fraxinus for hardwood species should be preferred when choosing species for forestry plantation, as they performed better in terms of BAI and $i W U E$ ratio.
\end{abstract}

Keywords Carbon isotope composition · Forest productivity $\cdot$ Plantations $\cdot$ Tree growth $\cdot$ Water-use efficiency

\section{Introduction}

Forests contribute to the reduction of atmospheric $\mathrm{CO}_{2}$ concentrations and help to mitigate climate change (Grassi et al. 2017). In recent decades, increasing temperatures,

Communicated by ZHU.

Tiziana Gentilesca

tizianagentilesca@gmail.com

1 School of Agricultural, Forest, Food and Environmental Sciences, University of Basilicata, Potenza, Italy

2 Department of Environmental, Biological and Pharmaceutical Sciences and Technologies, University of Campania “L. Vanvitelli”, Caserta, Italy

3 Pyrenean Institute of Ecology (IPE-CSIC), Zaragoza, Spain

4 Department of Agricultural Sciences, University of Naples "Federico II", Via Università, 100, 80055 Portici, Italy water scarcity and the highest frequency of extreme weather events have been observed especially in Mediterranean areas (Giorgi and Lionello 2008; Ripullone et al. 2009a). In this scenario, forest-based mitigation strategies-including afforestation, reforestation and reducing deforestation-are important to reduce atmospheric $\mathrm{CO}_{2}$ and increase $\mathrm{C}$ sequestration (Reyer et al. 2009). These practices favor rapid tree growth and carbon sequestration in post-harvest wood products (Harmon and Marks 2002; Kobziar and Stephens 2006; Krankina and Harmon 2006).

Some forestry practices that apparently mitigate global warming such as afforestation activities may actually intensify water use and, therefore, deplete available water reserves (Unkovich et al. 2003; Dias de Oliveira et al. 2005). For example, plantations composed of highly productive species used for bioenergy production generally use much more water than the species naturally occurring in these areas (Jackson et al. 2005). Moreover, certain management 
practices, such as the use of nitrogenous fertilizers for agriculture and forestry, in some cases may also reduce wateruse (Lauteri et al. 1997; Farley et al. 2005; Battipaglia et al. 2017), likely due to interacting effects with drought or nutrient imbalance, leading to interspecific differences in the water-use responses to nitrogen fertilization (Smith and van den Driessche 1992; Ripullone et al. 2004).

Biomass production and intrinsic water-use efficiency ( $i W U E$, as the ratio between carbon assimilation and water transpired) are important parameters that should be considered when choosing tree species for plantations. Although rapid biomass accumulation in fast-growing trees (short rotation forestry) is important in the interests of resource management and environmental sustainability, water consumption (related to the tree water-use and water lost by transpiration) should also be taken into account. Therefore, forest management should preferably focus on species and silvicultural practices that increase $\mathrm{C}$ sequestration without reducing groundwater reserves (Unkovich et al. 2003; Dias de Oliveira et al. 2005). Consequently, the choice of trees for use in plantations must factor in both the growth potential and the water use of each candidate species.

Sustainable water management in forested areas (i.e. afforestation, plantation, short rotations) is possible when the carbon to water balance ratio is considered. Under limited water conditions which frequently occur in the Mediterranean, plants partially close their stomata to save water and maintain their leaf water potential within a safety range to prevent cavitation (Ripullone et al. 2009a). Although stomatal control favours water saving, it has a negative effect on plant carbon uptake by down-regulating the $\mathrm{CO}_{2}$ assimilation (Jarvis and Davies 1998). The intrinsic water-use efficiency ( $i W U E$ ), assessing the ratio between $\mathrm{CO}_{2}$ assimilation and stomatal conductance, is a key parameter in droughtprone areas (Ripullone et al. 2009b; Altieri et al. 2015). Understanding species-specific differences in $i W U E$ may help to elucidate how plantation and afforestation stands respond to drought occurrence.

The carbon isotope composition $\left(\delta^{13} C\right)$ is a useful proxy to improve understanding of forest responses to climatechanging conditions over time (McCarrol and Loader 2004); it contributes to determining whether a plant species saves water as indirectly related to water-use efficiency (Farquhar et al. 1989a). There is a relationship between $i W U E$ and $\delta^{13} \mathrm{C}$ because of their independent linkages to the ratio of internal to ambient $\mathrm{CO}_{2}$ concentrations $\left(c_{\mathrm{i}} / c_{\mathrm{a}}\right)$. Studies have reported an increase in $i W U E$ around the globe (Loader et al. 2011; Marchand et al. 2020) and Mediterranean areas (Andreu-Hayles et al. 2011), even if higher $i W U E$ does not always translate into enhanced tree growth (Peñuelas et al. 2011; Silva and Anand 2013; and others). In open field studies, no clear pattern emerged, reporting both active and passive plant response: in the first case $c_{\mathrm{i}}$ increases more slowly than $c_{\mathrm{a}}$ due to photosynthetic plasticity, resulting in higher $i W U E$ (Duquesnay et al. 1998; Feng 1999; Peñuelas et al. 2008; Guerrieri et al. 2019), while the second case no changes in the $c_{\mathrm{a}}-c_{\mathrm{i}}$ are highlighted in response to increased atmospheric $\mathrm{CO}_{2}$ concentration $\left(c_{\mathrm{a}}\right)$, which resulted in no improvement of the $i W U E$ (Marshall and Monserud 1996). Saurer et al. (2014) suggested that site-specific conditions are relevant due to enhanced $i W U E$ in temperate forests of central Europe following a decreasing soil-water availability as a consequence of the ongoing climate change. However, multi-species studies carried out in Mediterranean areas focusing on variations in terms of $i W U E$ growth and plant ecophysiological adjustments are lacking.

We hypothesized that the ongoing climate change should favour $i W U E$ but disadvantage the growth as a consequence of enhancing drought events which negatively affect photosynthetic activity in both conifer and hardwood studied species. To test this idea, we investigated the magnitude of the co-variations in $B A I$ and $i W U E$ across species growing in forestry plantations. We considered contrasting environmental conditions in an afforested stand with conifer species (Pinus halepensis and Cupressus sempervirens) and in a coexisting stand with hardwood species (Quercus robur, Juglans regia, Fraxinus excelsior, and Populus spp), among the most common species used in the past for plantations in Italy. Specifically, we evaluated: (1) the growth in terms of basal area increment $(B A I)$; (2) the intrinsic water-use efficiency $(i W U E)$ as assessed by $\delta^{13} C$ in annual tree rings, and (3) the short-term species-specific ecophysiological adjustments, derived from $i W U E$.

\section{Materials and methods}

\section{Study sites}

The experiments were conducted at Camisano in northern Italy (Site 1) and at Gallipoli Cognato and Piccole Dolomiti Lucane Regional Parks in southern Italy (Site 2), Table 1.

Site 1 lies in the Padan basin and belongs to a flat area located $\sim 30 \mathrm{~km}$ east of Milan in northwestern Italy. The climate is classified as mild continental with an average total annual rainfall of $1050 \mathrm{~mm}$, almost equally distributed throughout the year. Maximum precipitation occurs during fall and winter and the average temperature is $10{ }^{\circ} \mathrm{C}$. The natural vegetation of the Padan basin is a mixed hardwood forest consisting of Quercus robur, Populus spp., Carpinus spp., Alnus spp., Salix spp., Fraxinus spp., and other trees indigenous to central Europe. The site is a mixed-species plantation established at the beginning of 1997 and covering 2.8 ha. The above-mentioned species, ecologically and economically important (Colpi et al. 1999), are widely employed in plantations in Italy especially from the $1960 \mathrm{~s}$ 
Table 1 Main characteristics of sites and sampled trees

\begin{tabular}{|c|c|c|c|c|c|c|}
\hline & Lat & Long & Altitude ( $\mathrm{m}$ asl) & Sampled spp. & dbh & se \\
\hline \multirow[t]{4}{*}{ Site 1} & \multirow[t]{4}{*}{$45^{\circ} 27^{\prime} 08.7^{\prime \prime} \mathrm{N}$} & \multirow[t]{4}{*}{$9^{\circ} 45^{\prime} 40.7^{\prime \prime} \mathrm{E}$} & \multirow[t]{4}{*}{92} & Juglans & 34.83 & 1.47 \\
\hline & & & & Fraxinus & 25.75 & 0.83 \\
\hline & & & & Quercus & 23.58 & 0.35 \\
\hline & & & & Populus & 32.00 & 0.95 \\
\hline \multirow[t]{2}{*}{ Site 2} & \multirow[t]{2}{*}{$40^{\circ} 32^{\prime} 44.46^{\prime \prime} \mathrm{N}$} & \multirow[t]{2}{*}{$16^{\circ} 5^{\prime} 17.66^{\prime \prime} \mathrm{E}$} & \multirow[t]{2}{*}{550} & Pinus & 21.32 & 1.83 \\
\hline & & & & Cupressus & 20.42 & 1.91 \\
\hline
\end{tabular}

to 1990 s of the last century covering more than one million hectares.

The plantation consisted of a main plot $(P l)(\sim 2.8$ ha $)$ with coexisting coetaneous species (Quercus robur, Fraxinus excelsior, and Juglans nigra), and monospecific Populus alba (clone a4) rows (P2), surrounding the main plot. The trees in $P 1$ and $P 2$ were planted in straight rows spaced $5 \mathrm{~m}$ apart corresponding to a density of $\sim 400$ trees per hectare. The crop cycle in $P 1$ and $P 2$ is different: hardwood species in $P 1$ and Populus trees in $P 2$ are managed as arboriculture and short rotation (for biomass energy), respectively. This implies a shorter cultivation cycle for Populus, that showed a different age (9 years old) compared to the other hardwood species (16 years old) sampled in P1. Nevertheless, Populus trees were considered as widely employed species representing a useful reference for biomass production and water use.

Site 2 belongs to a mountain stand located in the South of Italy; the bedrock is an arenaceous stone "Flysch di Gorgoglione" (alternating sandstone, marl, and clay) and the soil texture is mainly sand. The climate is the Mediterranean with a mean total annual rainfall of $687 \mathrm{~mm}$, concentrated in fall and winter, and an average temperature of $12^{\circ} \mathrm{C}$. There is a dry period from June to September during which precipitation is $<100 \mathrm{~mm}$. The stand studied here $(\sim 150 \mathrm{ha})$ was planted at the end of the 1960s with trees in rows $3 \mathrm{~m}$ apart with an overall stand density of $\sim 1200$ trees ha ${ }^{-1}$. The stand is dominated by Pinus halepensis $(\mathrm{P})$ and Cupressus glabra (C); together, they comprise $\sim 90 \%$ of the vegetation cover and their presence is shared at approximately 50\%. In addition, other species such as Phillyrea angustifolia, Pistacia lentiscus, and Ostrya carpinifolia are present. The selected stands belong to a managed area where during 2000s ordinary thinning, with a reduction of $20 \%$ of standing biomass, were applied.

\section{Sampling}

In spring 2015, 7 and 15 healthy dominant trees representative of each considered species were sampled at the plantation (Site 1) and afforestation (Site 2) stands, respectively. Two wood cores were extracted with an incremental borer at collar level and breast height for each tree at Site 1 and Site 2 , respectively.
Samples were air-dried and polished with a scalpel until the lumens of the vessels and tracheids were clearly visible. Tree-ring series were visually cross-dated and ring widths were measured at a $0.01-\mathrm{mm}$ resolution with an incremental measuring table Lega SMIL3 (Corona et al. 1989). Chronologies were checked within a species and site with Cofecha (Holmes 1983).

In our study, we considered even-aged plantations with poplar trees, managed as short rotation forestry that were slightly younger compared to the hardwood tree species sampled at Site 1. Therefore, to evaluate tree productivity in the selected stands by accounting for the age-effect, the raw chronologies were converted into tree basal area increments (BAI) as follows:

$\mathrm{BAI}_{t}=\pi r_{t}^{2}-\pi r_{t-1}^{2}$

where BAI at year $t$ is the annual ring area; and $r_{t}$ and $r_{t-1}$ are the stem radii at the end and beginning of the annual increment, respectively. BAI eliminates the age effect associated with stem geometry, reduces low-frequency variability, and obviates the need for detrending (Biondi 1999).

\section{Stable $\mathrm{C}$ isotope analysis}

For each species, five trees were selected for isotopic analyses. From each dated tree core, single rings were separated with a blade cutter. Each sample was ground in a centrifugal mill (ZM 1000, Retsch, Germany) with a 0.5-mm mesh size to ensure homogeneity. Isotopic analysis was performed on whole wood samples in hardwood species since recent studies have shown that the use of whole-wood isotope values is justified for ecophysiological and dendrochronological studies that analyze the response of trees to environmental changes recorded within the sapwood in a relatively short-term period (Borella et al. 1998; Harlow et al. 2005; Riechelmann et al. 2016). However, in conifer species isotopic analysis was performed on cellulose samples, to avoid biases on isotope value due to contamination by other wood extractives (Borella et al. 1998; D'Alessandro et al. 2004). For the extraction of cellulose a two-step digestion process was followed (Boettger et al. 2007; Battipaglia et al. 2008). The method is based on a double step digestion: first step 
was performed for the extraction of resin, fatty acids, ethereal oils and hemicellulose with a solution of $5 \% \mathrm{NaOH}$ for $2 \mathrm{~h}$ at $60{ }^{\circ} \mathrm{C}$ - this operation was repeated twice. In the second step, lignin was extracted with a $7 \% \mathrm{NaClO}_{2}$ solution for a minimum of $36 \mathrm{~h}$ at $60{ }^{\circ} \mathrm{C}$. Because the solution is only reactive for about $10 \mathrm{~h}$, it was changed daily and refilled as necessary. This step was repeated until the sample was "white", which is a characteristic that can be determined by experience or by comparison with commercial cellulose (Boettger et al. 2007). Finally, samples were washed three to four times with boiling distilled water (until $\mathrm{pH}=7 \pm 1$ ) and dried overnight at $50{ }^{\circ} \mathrm{C}$.

$0.06 \mathrm{mg}$ wood and alpha-cellulose material were weighed in tin capsules, for hardwood and conifer species, respectively. Stable C isotope composition was measured at the IRMS-SUN Laboratory (Caserta, Italy) by a combustion in an elemental analyzer (Carlo Erba, 1110 Milano, Italy) connected via a CONFLO II interface (Thermo Finnigan, Breen, Germany) to an isotope ratio mass-spectrometer (Delta V Advantage, Thermo Electron Corporation, Bremen Germany) operating in the continuous flow mode. Isotopic compositions are expressed in delta notation (\%) relative to an accepted reference standard: Vienna PeeDee belemnite for carbon isotope values. The standard deviation for the repeated analysis of an internal standard (commercial cellulose) was $<0.01 \%$.

\section{Calculation of iWUE from $\mathrm{C}$ isotope ratios}

Carbon isotope composition in tree rings $\left(\delta^{13} C\right)$ reflects the variations in the $\mathrm{CO}_{2}$ concentration ratio between the leaf intercellular spaces and the atmosphere $\left(c_{\mathrm{i}} / c_{\mathrm{a}}\right)$. These are related to changes in carbon assimilation $(A)$ or stomatal conductance $\left(g_{\mathrm{s}}\right)$. A simplified version of the Farquhar equation (Farquhar et al. 1989b) determines the $\delta^{13} C$ in plant material $\left(\delta^{13} C_{\mathrm{p}}\right)$ as follows:

$\delta^{13} C_{\mathrm{p}}=\delta^{13} C_{\mathrm{a}}-a-(b-a) \frac{c_{\mathrm{i}}}{c_{\mathrm{a}}}$

where $\delta^{13} C_{\mathrm{a}}$ and $c_{\mathrm{a}}$ indicate the isotopic signature of atmospheric $\mathrm{CO}_{2}, a$ is the fractionation against ${ }^{13} \mathrm{CO}_{2}$ during diffusion through stomata (4.4\%), and $b$ is the fractionation during carboxylation (27\%) by the $\mathrm{CO}_{2}$-fixing enzyme rubisco. In the $i W U E$ calculation, the mesophyll conductance of $\mathrm{CO}_{2}$ (Seibt et al. 2008) and post-photosynthetic processes that may potentially affect tree-ring $\delta^{13} C$ (Gessler et al. 2014; Frank et al. 2015) were not considered. Since $c_{\mathrm{i}} / c_{\mathrm{a}}$ and $\delta^{13} C$ are reciprocally linked, the latter is indicative of changes in the $i W U E$, which is the ratio between $A$ and the stomatal conductance to water vapor $\left(g \mathrm{H}_{2} \mathrm{O}\right)$ according to Ehleringer et al. (1993):
$\mathrm{WUE}_{i}=\frac{A}{g_{\mathrm{H} 2 \mathrm{O}}}=\frac{\left(c_{\mathrm{a}}-c_{\mathrm{i}}\right)}{1.6}$

From Eq. (1), $c_{\mathrm{i}}$ is calculated as follows:

$c_{\mathrm{i}}=c_{\mathrm{a}} \frac{\delta^{13} C_{\mathrm{a}}-\delta^{13} C_{\mathrm{p}}-a}{b-a}$

Therefore the Eq. (2) can be solved as follows:

$\mathrm{WUE}_{i}=\frac{A}{g_{\mathrm{s}}}=\frac{c_{\mathrm{a}}-c_{\mathrm{i}}}{1.6}=\frac{c_{\mathrm{a}}}{1.6} \times\left(\frac{b-\delta^{13} C_{a}+\delta^{13} C_{p}}{b-a}\right)$

where $\delta^{13} C_{\mathrm{a}}$ and $c_{\mathrm{a}}$ values were obtained from Mauna Loa records (Keeling et al 2001); 1.6 is the molar diffusivity ratio of $\mathrm{CO}_{2}-\mathrm{H}_{2} \mathrm{O}$ (i.e., $g_{\mathrm{CO} 2}=g_{\mathrm{H} 2 \mathrm{O}} / 1.6$ ); the values $a$ and $b$ are known, $c_{\mathrm{i}}$ is calculated from Eq. (3), $\delta^{13} C_{\mathrm{p}}$ is the carbon isotope composition measured in tree rings.

\section{Statistical analyses}

The six tree species sampled were subdivided into the hardwood species Juglans nigra, Quercus robur, Populus spp., and Fraxinus excelsior (Site 1) and the conifers Pinus halepensis and Cupressus glabra (Site 2). BAI data were log-transformed before analysis to meet the normality assumptions. The $L M M$ was fitted to assess the effect of age, species, $i W U E$ and their interactions (fixed factors) on $B A I$, where individual trees were considered as random effects to account for repeated measures within a site. Following Zuur et al. (2009), the most parsimonious models were selected starting with a saturated model where the fixed component contained all explanatory variables and their possible interactions, using the ' $n$ lme' package (Pinheiro et al. 2020) from R environment v.4.0.0 (R Core Team 2020). Fixed terms were centered and scaled to improve parameter estimates and allow direct comparisons of the regression coefficients. We then optimized the random-effect structure of the model, testing whether including extra random-effect terms (i.e., random slopes) for tree ID improved the fit of the model; different random structures were compared through a Likelihood Ratio Test (LRT, which approximately follows a chi-square distribution; Zuur et al. 2009). When comparing saturated models that varied in their random structure but not fixed effects, the models were fit using restricted maximum likelihood (REML) to avoid biased estimators for the variance terms. The fixed-effect structure was optimized by fitting the model with Maximum Likelihood (ML), rather than REML, to prevent biased fixed-effect parameter estimates. We conducted AICc values (Akaike Information Criterion corrected for sample size) based on multi-model inference using the "MuMIn" dredge function (Barton and Barton 
2020) to run a complete set of models with all possible combinations of the fixed effects, with $\Delta \mathrm{AICc}<2$ interpreted as substantial support that the model belongs to the set of ten best models, $\triangle \mathrm{AICc}$ of 4-7 corresponding to less support and $\triangle \mathrm{AICc}>10$ treated as providing no support that the model belongs to the best (Burnham and Anderson 2002). Finally, models were refitted with REML to estimate model parameters. Marginal and conditional $R^{2}$ scores (Nakagawa and Schielzeth 2013) were calculated to examine the variation explained by models using the "r.squaredGLMM" function in the "MuMIn" package. The residual diagnosis was performed to check the validity of the model assumptions (normality and homoscedasticity of residuals). Subsequently, the lstrends function from the 'Ismeans' R package (Lenth 2016) was used to estimate and compare, via Tukey post-hoc test, species-specific slopes of fitted lines.

For each species, we further evaluated the temporal pattern of $i W U E$ components (i.e. $c_{\mathrm{i}}, c_{\mathrm{i}} / c_{\mathrm{a}}, c_{\mathrm{a}}-c_{\mathrm{i}}$ ), by inspecting the slope of the regression line via LMMs where cambial age was included as fixed-term and sampled trees as random. The models were then parametrically bootstrapped 1000 times using the bootMer function in package 'Ime4' (Bates et al 2015) from which the predicted median and 95\% confidence interval of the beta estimates were calculated.

\section{Results}

\section{Basal area increment and intrinsic water-use efficiency}

In general, a substantial range of variation of $i W U E$ and $B A I$ was observed (Fig. 1). For all hardwood species, except Populus, different $B A I$ was measured for similar $i W U E$ distribution ranges. Conifers showed contrasting differences between the recorded variables, i.e., Cupressus showed greater water-use efficiency, but was less productive in terms of tree growth than Pinus.

The hardwood species all had similar annual $i W U E$ during 1996-2010, except for Populus (Fig. 1a). The $i W U E$ for the conifers showed higher interannual variability compared to the considered hardwood species (coefficient of variation was $12.5 \%$ and $10.4 \%$ for conifers and hardwood, respectively). $B A I$ and $i W U E$ variations at Site 2 were observed in correspondence to the thinning operations in both Cupressus and Pinus stands, which likely occurred in 2003 and 2009 (Fig. 1). The $i W U E$ for Pinus was significantly lower than Cupressus (Fig. 1b); overall, Cupressus exhibited the lowest $B A I$ (Fig. 1c) whereas Populus the highest $\left(\sim 2500 \mathrm{~mm}^{2}\right)$, which was also the youngest sampled tree species at Site 1 (Fig. 1c).

\section{The role of iWUE in determining BAI}

Species characterized by different strategies for achieving high/low $B A I$ in relation to high/low values of $i W U E$ were depicted (Fig. 2a). In particular, among hardwood species, Populus showed the highest $i W U E$ value while Fraxinus displayed the lowest value. Between conifer species, Cupressus showed the lowest and Pinus the highest $i W U E$ value per $B A I$. Figure $2 \mathrm{~b}$ describes the slopes of the species of $B A I$ on $i W U E$, whereas the model structures, covariates with model coefficients, standard errors, and significance levels are summarized in the Supplementary Table S1. In particular, the selected model showed that $71 \%$ of the total variance was attributable to the fixed effects whereas less than $1 \%$ of the variance was attributable to variation between trees. While no evidence for a main effect of $i W U E$ on $B A I$ was found, differences among species (Supplementary Table S2) are evident where the slopes of the relations with BAI of Populus and Pinus are significantly higher and lower respectively compared to the main effect (i.e. Cupressus), while an opposite slope was observed for Quercus (Fig. 2b). As expected, tree age had a negative influence on $B A I$.

\section{Variations in the iWUE components}

In general increasing $c_{\mathrm{i}}$ and $c_{\mathrm{i}} / c_{\mathrm{a}}$ trends were observed with differential $i W U E$ trends, as assessed by $c_{\mathrm{a}}-c_{\mathrm{i}}$ temporal variations (Table 2). In particular, the following main results for $c_{\mathrm{a}}-c_{\mathrm{i}}$ were observed: a significant increasing trend for Cupressus and a significant decreasing trend for Fraxinus, Juglans, and Quercus species; relatively decreasing, and non-significant trends for Pinus and Populus species. Nonsignificant variations for $c_{\mathrm{i}} / c_{\mathrm{a}}$ were recorded for Cupressus and Pinus, respectively, whereas positive significant trends were recorded for Fraxinus, Juglans, Populus, and Quercus species.

Overall $c_{\mathrm{i}} / c_{\mathrm{a}}$ ratios varied among species showing lower values in conifers than hardwood species (Fig. 3a); a consistent $c_{\mathrm{i}}$ adjustment with respect to the increasing $c_{\mathrm{a}}$ was evident in all considered species, although a short-term period was considered (Fig. 3b).

\section{Discussion}

In this study, we analyzed the $i W U E$ and BAI in a range of tree species, mostly used in Italy in former forestry plantation practices to provide functional-based indications on tree species selection.

The observed strategies for achieving (relatively) high/ low $i W U E$ (Fig. 2a) are closely related to differences in physiological mechanisms among species. Indeed, different $i W U E$ levels may be linked to a greater overall $\mathrm{CO}_{2}$ 

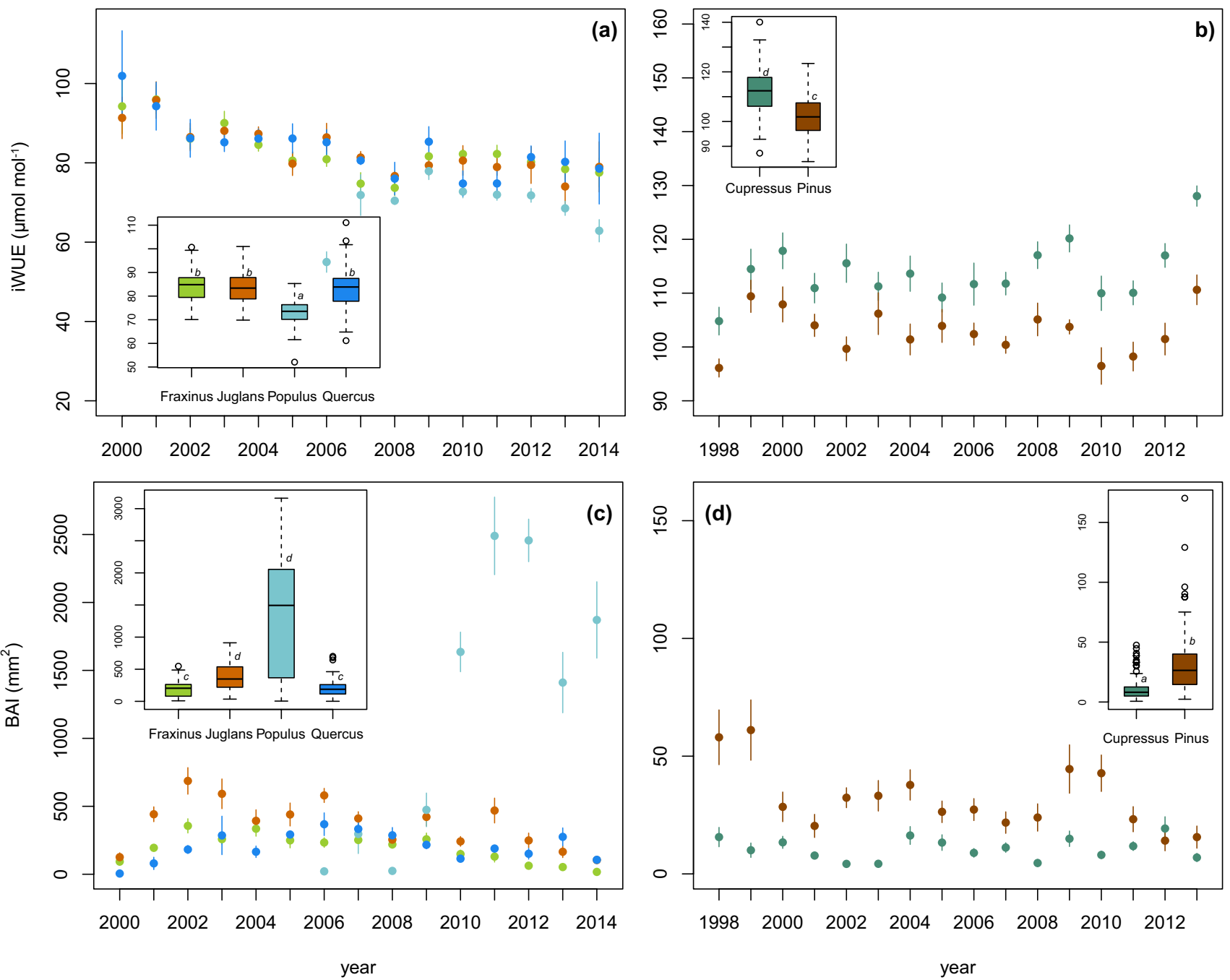

Fig. 1 Temporal variation in intrinsic water use efficiency (iWUE, upper panels) and basal area increment (BAI, lower panels) for plantation (a, c) and afforestation stands $(\mathbf{b}, \mathbf{d})$ over the studied period. Points with different colors represent means of different species in each year; bars are standard errors. Insets represents boxplots of species-specific $i W U E$ and $B A I$. Each box represents the 75 th-25th per-

assimilation capacity of some species or a better stomatal control in other species. Populus was distinct from the other species due to its $i W U E$ comparatively low coupled to a high growth rate, whilst Juglans and Fraxinus appeared to have reached a better carbon-water balance, although showing a weak association between considered variables (Fig. 2b). On the contrary, the opposite associations between BAI and $i W U E$ reported for Quercus may be explained by a greater stomatal control compared to the other coexisting species i.e. avoiding water loss by stomatal closure and, consequently, enhancing $i W U E$ to the detriment of growth. Similar findings have also been reported in previous studies in both seedlings, under controlled environmental conditions (Picon et al. 1996), and adult trees, growing in natural forests centiles, the bold line shows the median, upper and lower marks are the largest to smallest observation values which are less than or equal to the upper and lower quartiles plus 1.5 times the length of the interquartile range. Circles outside the lower-upper mark range represent outliers. Different letters indicate significant differences among species $(P \leq 0.05)$ Tukey's pairwise post-hoc comparisons

subjected to dieback phenomena not far from experimental Site 1 (Colangelo et al. 2018).

One of our objectives was to understand the magnitude of the co-variations in BAI and $i W U E$ across species growing in a forestry plantation. When considering growth (in terms of BAI) as explained by plant ecophysiological trait $(i W U E)$, age and species, our results did not support evidence for a general trade-off between annual growth and $i W U E$. A flat or weak relationship was observed for Juglans, Fraxinus, and Pinus species; positive relationships for Populus and Cupressus while a negative relationship was found for Quercus (Fig. 2b).

This general uncoupling between $i W U E$ and BAI has been widely observed in literature. Indeed, several studies 


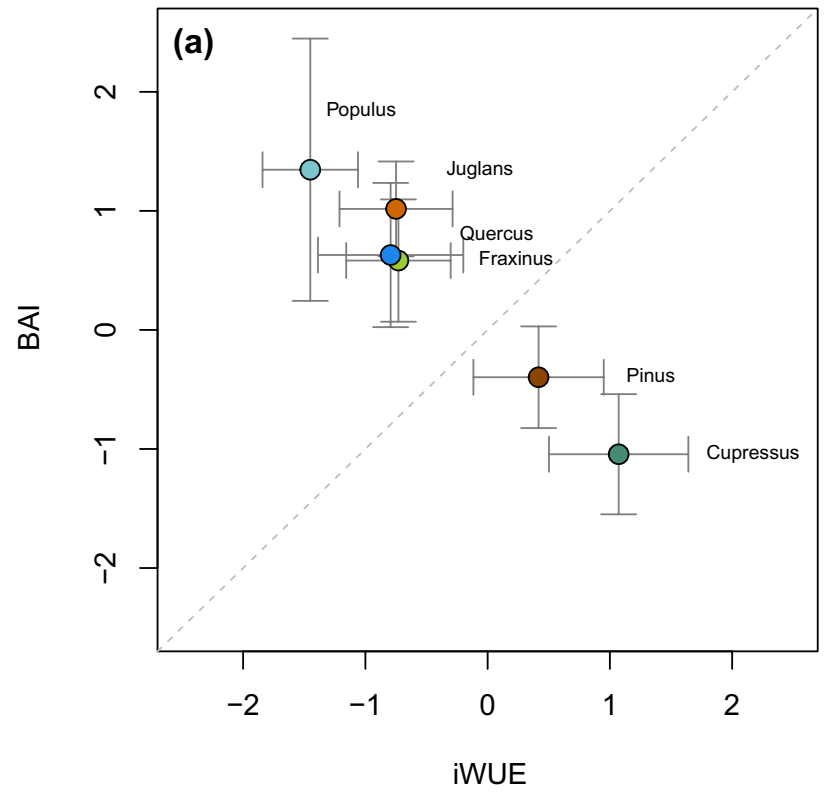

Fig. 2 The relationship between $B A I$ and $i W U E$ is represented in both panels. In a circles and bars represent mean values and standard deviations for each investigated tree species; the dashed lines shows 1:1 relationship. b Shows comparison via Tukey post-hoc test

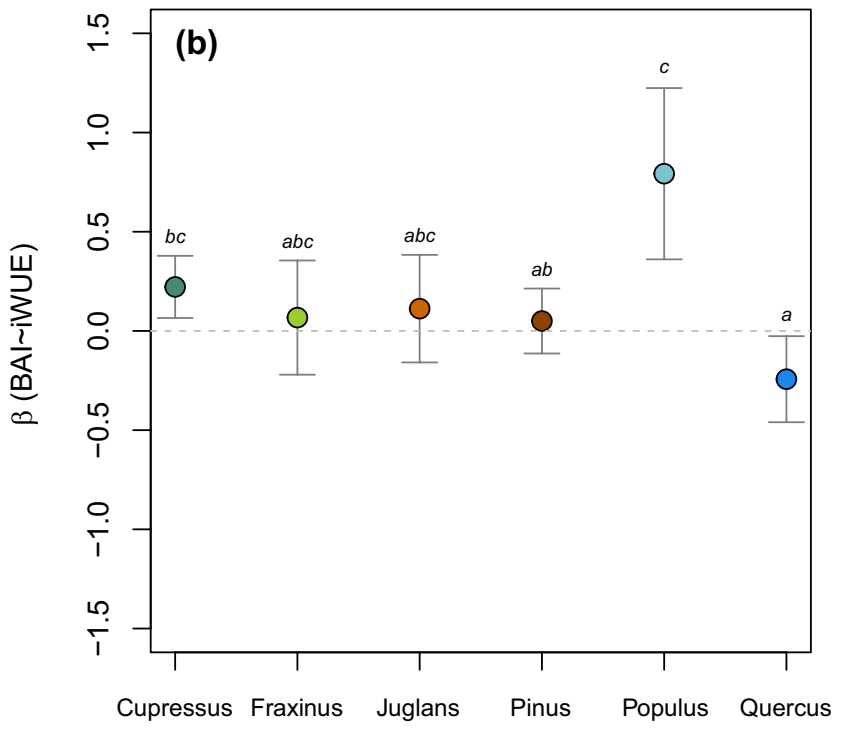

of species-specific slopes of the relationship $B A I-i W U E$ from fitted LMM. Different letters indicate significant differences among species at $P \leq 0.05$
Table 2 Observed temporal patterns in components of intrinsic water-use efficiency

\begin{tabular}{|c|c|c|c|c|c|c|}
\hline \multirow[t]{3}{*}{ Species } & \multicolumn{6}{|c|}{ Parameters } \\
\hline & \multicolumn{2}{|l|}{$c_{\mathrm{i}}$} & \multicolumn{2}{|l|}{$c_{\mathrm{i}} / c_{\mathrm{a}}$} & \multicolumn{2}{|l|}{$c_{\mathrm{a}}-c_{\mathrm{i}}$} \\
\hline & $\beta$ & $\mathrm{CI}$ & $\beta$ & $\mathrm{CI}$ & $\beta$ & $\mathrm{CI}$ \\
\hline Cupressus & -0.001 & $(-0.014$ to 0.011$)$ & -0.010 & $(-0.023$ to 0.001$)$ & 0.019 & $(0.005-0.032)$ \\
\hline Fraxinus & 0.063 & $(0.0418-0.085)$ & 0.062 & $(0.040-0.082)$ & -0.060 & $(-0.081$ to 0.038$)$ \\
\hline Juglans & 0.0733 & $(0.0524-0.095)$ & 0.070 & $(0.048-0.092)$ & -0.065 & $(-0.089$ to -0.042$)$ \\
\hline Pinus & 0.016 & $(0.0061-0.026)$ & 0.009 & $(-0.001$ to 0.020$)$ & -0.005 & $(-0.016$ to 0.006$)$ \\
\hline Populus & 0.043 & $(0.004-0.083)$ & 0.015 & $(-0.033$ to 0.064$)$ & -0.019 & $(-0.073$ to 0.029$)$ \\
\hline Quercus & 0.0789 & $(0.050-0.106)$ & 0.064 & $(0.037-0.091)$ & -0.055 & $(-0.082$ to 0.027$)$ \\
\hline
\end{tabular}

$\beta$ values correspond to the bootstrapped slope of the fitted LMMs with the cambial age as covariate and tree ID set as random. Bold values indicate the statistical significance at $P \leq 0.05$; the $95 \%$; $C I$, estimated confidence intervals in parenthesis report that the enhanced $i W U E$ observed in the last century (Andreu-Hayles et al. 2011; Leonardi et al. 2012; Frank et al. 2015; Marchand et al. 2020) did not translate into an increase in tree growth (Peñuelas et al. 2011; Silva and Anand 2013; Lévesque et al. 2014). Moreover, site-specific studies are often carried out in open-fields along a latitudinal gradient to appreciate species-specific adaptations to changing climatic conditions by evaluating plant physiological traits adjustments (Guerrieri et al. 2019; Fu et al. 2020). In general, contrasting relationships between $B A I$ and $i W U E$, e.g. a negative relationship for conifer whereas positive relationships for hardwood species (Scots pine and European beech in González de Andrès et al. 2018) were evident; no common patterns were observed when intra-specific comparisons were carried out (González-Muñoz et al. 2015) and very few studies have been carried out on plantations, i.e. clones of Populus (Rasheed et al. 2019). A recent review (Walker et al. 2020) suggested a major increase in $i W U E$ in water-limited regions where long-term transpiration is primarily precipitation driven (i.e. plants use the available water).

Most species considered in our study did not report substantial time-related enhanced BAI and $i W U E$, showing rather flat or even negative trends (Table 2). This is in contrast with the latest literature (Peñuelas et al 2008; Battipaglia et al. 2013; Guerrieri et al. 2019; Walker et al. 


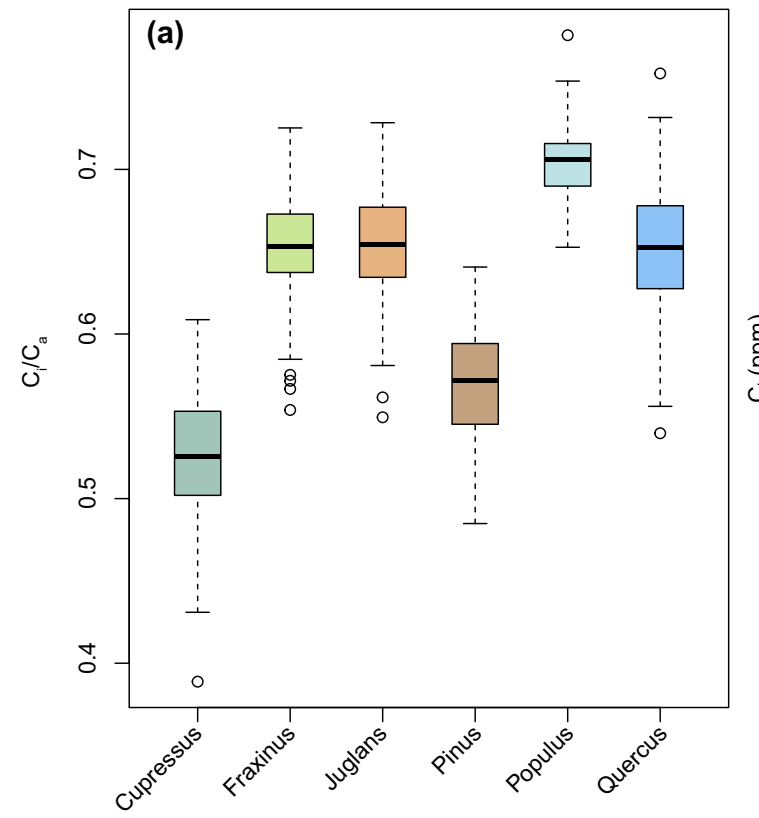

Fig. 3 a Boxplots of ratio between intercellular to ambient carbon dioxide concentration for considered species. Each box represents the 75th-25th percentiles, the bold line shows the median, upper and lower marks are the largest to smallest observation values which are less than or equal to the upper and lower quartiles plus 1.5 times the length of the interquartile range. Circles outside the lower-upper mark range represent outliers. b Temporal species-specific relation-

2020) where an increase in $i W U E$ is reported. No evidence of increased carbon uptake per unit water loss has been recognized, in agreement with literature studies (Huang et al. 2007; Peñuelas et al. 2008, 2011; Andreu-Hayles et al. 2011; Franks et al. 2013). This could reflect a water-saving strategy in which the stomata are closed, thereby enhancing $i W U E$ (Battipaglia et al. 2013) or even a climate-related effect, indeed, in some cases, the trade-off carbon uptake per water loss is strongly dependent on the occurrence across the years of favorable/unfavorable climatic conditions (Granda et al. 2014).

\section{Short-term species-specific adjustments}

Even short-term variations in the ratio and difference of intercellular to ambient $\mathrm{CO}_{2}$ concentrations can indicate species-specific acclimations to current environmental conditions. According to Saurer et al. (2004), we could observe three scenarios with respect to the possible responses of $c_{\mathrm{i}}$ to increasing $c_{\mathrm{a}}$ : (a) $c_{\mathrm{i}} / c_{\mathrm{a}}$ remains constant when the tree actively controls $c_{\mathrm{i}}$; (b) the increments in $c_{\mathrm{i}}$ and $c_{\mathrm{a}}$ are the same and $c_{\mathrm{i}}$ passively follows $c_{\mathrm{a}}$ and their relative differences do not change; (c) $c_{\mathrm{i}}$ transiently rises faster than $c_{\mathrm{a}}$ so that $c_{\mathrm{i}} / c_{\mathrm{a}}$ increases and $c_{\mathrm{a}}-c_{\mathrm{i}}$ decreases. The control of $c_{\mathrm{i}}$ (the capacity of the plant to reduce the impact of changes in $c_{\mathrm{a}}$, or

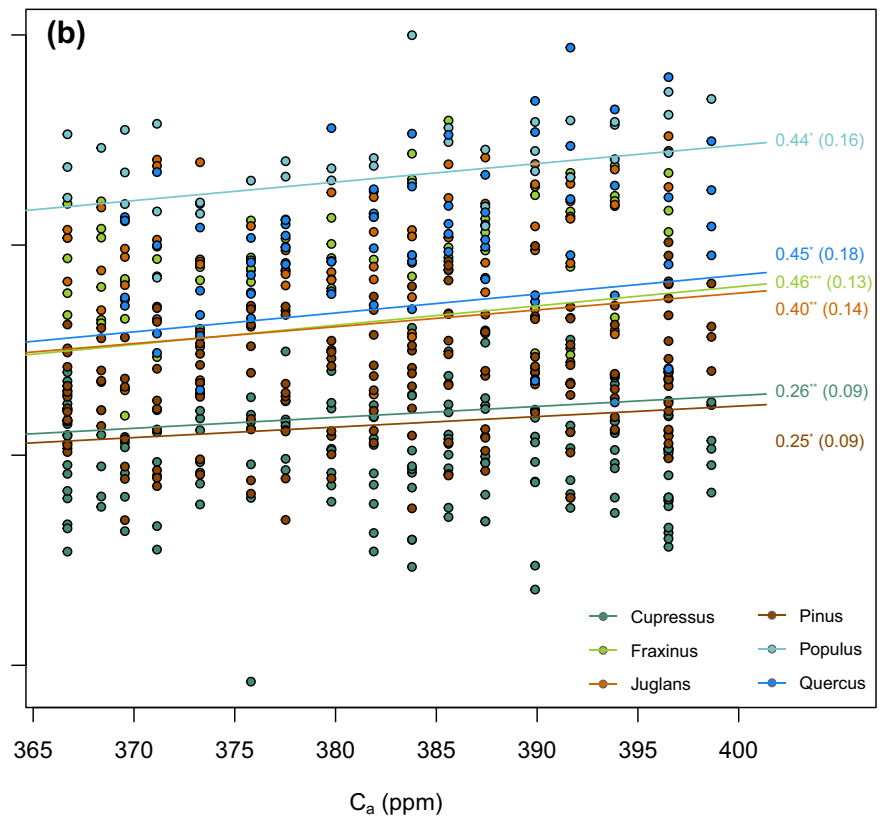

ships between ambient ( $c_{\mathrm{a}}, x$ axis) and intercellular $\left(c_{\mathrm{i}}, y\right.$ axis) carbon dioxide concentration; lines draw each predicted LMMs as a function of $c_{\mathrm{a}}$ and cambial age as covariates and tree ID set as random; slope coefficients and their standard error of coefficients (in bracket) are reported nearby fitted lines. $*$ and $* *$ indicate statistical significance for $P<0.05$ and $P<0.01$, respectively

$c_{\mathrm{i}}$ homeostasis) decreases from scenario (1) to (2) and from scenario (a) to (c )above.

Species-specific acclimations to recent increases in atmospheric $\mathrm{CO}_{2}$ concentrations were evaluated from temporal variations in the ratio and the differences between $c_{\mathrm{i}}$ and $c_{\mathrm{a}}$ (Fig. 3, Table 2). In general, the species considered in our study showed quite a similar behavior of $c_{\mathrm{i}}$ at the increasing $c_{\mathrm{a}}$ registered in the last few years, with lower $c_{\mathrm{i}} / c_{\mathrm{a}}$ ratios observed in conifers compared to hardwood trees (Fig. 3a). In agreement to published studies (Guerrieri et al. 2019) this evidence could underline species-specific differences in mesophyll conductance (Flexas et al 2008) and leaf photosynthetic components (Bahar et al. 2018). However, this increasing trend (Fig. 3b) did not directly translate in a common response of selected species when considering timerelated trends, accounting for cambial age and within tree variation (Table 2). Indeed, all species (except for Cupressus) showed flat $i W U E$ trends, possibly linked to variations in either $A$ or $g_{\mathrm{s}}$.

Our results at first confirm that not all tree species save water equally in either conifer and hardwood species (Leonardi et al. 2012; Saurer et al. 2014; Frank et al. 2015); also we must recognize that our study, although considering sites with quite similar climate variations (Figs. S1 and S2), considers artificial plantation areas of introduced tree species where site-specific conditions, in particular water 
table depths, are quite different. Indeed at Site 1, a greater available soil water reservoir for trees is vital to mitigate the occurrence of drought stress events; conversely, at Site 2 , conifer plantations are subjected to high temperatures and frequent drought episodes that would lower soil water potential, which can induce stomatal closure (McDowell et al. 2008) and reduce photosynthetic carbon uptake (Wang et al. 2017). At elevated temperatures, plants tend to close their stomata to prevent excessive water loss, increasing $i W U E$, as observed, for example, in pine forests on the Iberian Peninsula (Andreu-Hayles et al. 2011). Moreover, high temperature and extreme heat events can worsen drought stresses (Teskey et al. 2015) and exacerbate the effects of increasing $\mathrm{CO}_{2}$ concentrations on $i W U E$ (Norby and Zak 2011; Tognetti et al. 2014; Kwak et al. 2016).

In addition, the observed patterns could be partially related to differences in carbon allocation (e.g., increasing leaf area index or developing a deeper root system) among the species. Indeed, except for Populus, the hardwood species at Site 1 did not show enhanced growth in terms of basal area (Fig. 1c). Therefore, there is no evidence here to support an increase in $A$; a reduction in $g_{s}$ is most likely responsible for the observed decreasing $c_{\mathrm{a}}-c_{\mathrm{i}}$ patterns. In our data set, we observed constant $c_{\mathrm{i}} / c_{\mathrm{a}}$ trends correlated with an increase in $c_{\mathrm{a}}-c_{\mathrm{i}}$ and $i W U E$ for conifers while for broadleaves, flat or slightly increasing $c_{\mathrm{i}} / c_{\mathrm{a}}$ trends associated to a flat or slightly decreasing $c_{\mathrm{a}}-c_{\mathrm{i}}$ and $i W U E$ trends (Table 2). Our results suggest that conifers and Cupressus in particular, has the highest plasticity in terms of regulating stomata in response to rising atmospheric $\mathrm{CO}_{2}$ concentrations; as the increase in $i W U E$ was associated with constant $c_{\mathrm{i}} / c_{\mathrm{a}}$ In these specific cases, our observations support the hypothesis that there is an active mechanism maintaining a constant $c_{\mathrm{i}} / c_{\mathrm{a}}$ ratio associated with increased $i W U E$, as corroborated by previous studies (Peñuelas and Azcon-Bieto 1999; Feng 1999; Saurer et al. 2004; Peñuelas et al. 2008, 2011).

\section{Conclusions}

The following main conclusions can be drawn from our study:

1. $\quad B A I$ and $i W U E$ showed a high species-specific degree of variation depicting less and more efficient species within conifers and hardwood trees; site-specific climate conditions and water availability differentially influenced $i W U E$.

2. All the considered species showed similar short-term ecophysiological adjustments with respect to the ongoing rise in $\mathrm{CO}_{2}$ concentrations; in a few cases, the hypothesis of an active plant mechanism, maintaining a constant ratio between intercellular and ambient $\mathrm{CO}_{2}$ concentrations, was observed, i.e. Cupressus, the less productive and more water saving within the considered species.

3. Juglans, Fraxinus and Pinus seem to show the best performance in terms of carbon and water balance, providing functional-based indications on tree species selection for forestry plantations.

However, further studies incorporating a greater number of conifers and hardwood species are necessary; in this sense, this study can give first useful attempts.

Author contribution statement AMSF and FR supported and supervised the research, FR designed the research, MC and AL conducted fieldwork, TG and MC conducted lab work supervised by SA and GB; AR performed statistical analyses. TG wrote the paper with inputs from GB, MB and FR and all the authors contributed to the preparation of the final manuscript.

Supplementary Information The online version contains supplementary material available at https://doi.org/10.1007/s00468-021-02120-z.

Acknowledgements The authors thank Amalia Gialdini for assistance in the preparation of the samples for laboratory analysis. The valuable comments by four anonymous referees greatly contributed to improve the paper.

Funding Open access funding provided by Università degli Studi della Basilicata within the CRUI-CARE Agreement.. This research activity was funded by the Italian Ministry of Education, University, and Research (MIUR)-PRIN 2010-2011 Carbotrees prot. 201049EXTW_008 "National strategies for climate change mitigation in agro-forestry ecosystems." WP3 "Evaluation through experimental observations and physiological models of the relationship between $\mathrm{C}$ sequestration and transpired water (water-use efficiency)."

\section{Declarations}

Conflict of interest The authors declare that they have no conflict of interest.

Open Access This article is licensed under a Creative Commons Attribution 4.0 International License, which permits use, sharing, adaptation, distribution and reproduction in any medium or format, as long as you give appropriate credit to the original author(s) and the source, provide a link to the Creative Commons licence, and indicate if changes were made. The images or other third party material in this article are included in the article's Creative Commons licence, unless indicated otherwise in a credit line to the material. If material is not included in the article's Creative Commons licence and your intended use is not permitted by statutory regulation or exceeds the permitted use, you will need to obtain permission directly from the copyright holder. To view a copy of this licence, visit http://creativecommons.org/licenses/by/4.0/. 


\section{References}

Altieri S, Mereu S, Cherubini P, Castaldi S, Sirignano C, Lubritto C, Battipaglia G (2015) Tree-ring carbon and oxygen isotopes indicate different water use strategies in three Mediterranean shrubs at Capo Caccia (Sardinia, Italy). Trees Struct Funct 29(5):15931603. https://doi.org/10.1007/s00468-015-1242-z

Andreu-Hayles L, Planell O, Gutiérrez E, Muntan E, Helle G, Anchukaitis KJ, Schleser GH (2011) Long tree-ring chronologies reveal 20th century increases in wateruse efficiency but no enhancement of tree growth at five Iberian pine forests. Glob Change Biol 17:2095-2112

Bahar NHA, Hayes L, Scafaro AP, Atkin OK, Evans JR (2018) Mesophyll conductance does not contribute to greater photosynthetic rate per unit nitrogen in temperate compared with tropical evergreen wet-forest tree leaves. New Phytol. https://doi.org/10.1111/ nph. 15031

Barton K, Barton MK (2020) Package 'MuMIn' Version 1.43.17. https://CRAN.R-project.org/package=MuMIn

Bates D, Mächler M, Bolker B, Walker S (2015) Fitting linear mixedeffects models using lme4. J Stat Softw 67(1):1-48. https://doi. org/10.18637/jss.v067.i01

Battipaglia G, Jäggi M, Saurer M, Siegwolf RTW, Cotrufo MF (2008) Climatic sensitivity of $\delta^{18} \mathrm{O}$ in the wood and cellulose of tree rings: results from a mixed stand of Acer pseudoplatanus L. and Fagus sylvatica. Palaeogeogr Palaeocl 261:193-202

Battipaglia G, Saurer M, Cherubini P, Calfapietra C, McCarthy HR, Norby RJ, Cotrufo MF (2013) Elevated $\mathrm{CO}_{2}$ increases tree-level intrinsic water use efficiency: insights from carbon and oxygen isotope analyses in tree rings across three forest FACE sites. New Phytol 197:544-554

Battipaglia G, Pelleri F, Lombardi F, Altieri S, Vitone A, Conbte E, Tognetti R (2017) Effects of associating Quercus robur L. and Alnus cordata Loisel. on plantation productivity and water use efficiency. Forest Ecol Manag 391:106-114

Biondi F (1999) Comparing tree-ring chronologies and repeated timber inventories as forest monitoring tools. Ecol Appl 9:216-227

Boettger T, Haupt M, Knöller K (2007) Wood cellulose preparation methods and mass spectrometric analyses of $\delta^{13} \mathrm{C}, \delta^{18} \mathrm{O}$, and nonexchangeable $\delta^{2} \mathrm{H}$ values in cellulose, sugar, and starch: an interlaboratory comparison. Anal Chem 79(12):4603-4612

Borella S, Leuenberger M, Saurer M, Siegwolf R (1998) Reducing uncertainties in $\delta^{13} \mathrm{C}$ analysis of tree rings: pooling, milling and cellulose extraction. J Geophys Res 103(D16):19519-19526

Burnham KP, Anderson DR (2002) Model selection and multimodel inference: a pratical information-theoretic approach, 2nd edn. Springer, New York

Colangelo M, Camarero JJ, Ripullone F, Gazol A, Sánchez-Salguero R, Oliva J, Redondo MA (2018) Drought decreases growth and increases mortality of coexisting native and introduced tree species in a temperate floodplain forest. Forests 9(4):205

Colpi C, Pettenella D, Urbinati C (1999) Forestry in Italy. In: Pelkonen $\mathrm{P}$ et al (eds) Forestry in changing societies in Europe-Part II: Country reports. Silva Network

Corona P, Ferrara A, La Marca O (1989) Un sistema di misura delle ampiezze anulari: il dendrocronografo "Smil 3." L'Italia Forestale e Montana 5:391-404

D’Alessandro CM, Guerrieri MR, Saracino A (2004) Comparing carbon isotope composition of bulk wood and holocellulose from Quercus cerris, Fraxinus ornus and Pinus radiata tree rings. Forest@ 1:51-57. https://doi.org/10.3832/efor0217-0010051)

Dias de Oliveira ME, Vaughan BE, Rykiel EJ (2005) Ethanol as fuel: energy, carbon dioxide balances, and ecological footprint. Bioscience 55:593-602
Duquesnay A, Bréda N, Stievenard M, Dupouey JL (1998) Changes of tree-ring $\delta^{13} \mathrm{C}$ and water-use efficiency of beech (Fagus sylvatica L.) in north-eastern France during the past century. Plant Cell Environ 21:565-572

Ehleringer JR, Hall AE, Farquhar GD (1993) Water use in relation to productivity. In: Ehleringer JR, Hall AE, Farquhar GD (eds) Stable isotopes and plant carbon-water relations. Academic Press, New York, pp 3-8

Farley KA, Jobbagy EG, Jacksib RB (2005) Effects of afforestation on water yield: a global synthesis with implications for policy. Glob Change Biol 11:1565-1576

Farquhar GD, Ehlinger JR, Hubrick KT (1989a) Carbon isotope discrimination and photosynthesis. Annu Rev Plant Phys 40:503-537

Farquhar GD, Hubrick KT, Condon AG, Richards RA (1989b) Carbon isotope fractionation and plant water-use efficiency. In: Rundel PW, Ehleringer JR, Nagy KA (eds) Stable isotopes in ecological research. Springer-Verlag, New York, pp 21-40

Feng X (1999) Trends in intrinsic water-use efficiency of natural trees for the past 100-200 years: a response to atmospheric CO2 concentration. Geochim Cosmochim Ac 63:1891-1903

Flexas J, Ribas-Carbó M, Diaz-Espejo A, Galmés J, Medrano H (2008) Mesophyll conductance to $\mathrm{CO}_{2}$ : current knowledge and future prospects. Plant Cell Environ 31:602-621

Frank DC, Poulter B, Saurer M, Esper J, Huntingford C, Helle G, Treydte K, Zimmermann NE, Schleser GH, Ahlström A, Ciais P, Friedlingstein P, Levis S, Lomas M, Sitch S, Viovy N, AndreuHayles L, Bednarz Z, Berninger F, Boettger T, D'Alessandro CM, Daux V, Filot M, Grabner M, Gutierrez E, Haupt M, Hilasvuori E, Jungner H, Kalela-Brundin M, Krapiec M, Leuenberger M, Loader NJ, Marah H, Masson-Delmotte V, Pazdur A, Pawelczyk S, Pierre M, Planells O, Pukiene R, Reynolds-Henne CE, Rinne KT, Saracino A, Sonninen E, Stievenard M, Switsur VR, Szczepanek M, Szychowska-Krapiec E, Todaro L, Waterhouse JS, Weigl M (2015) Water-use efficiency and transpiration across European forests during the Anthropocene. Nat Clim Change 5:579-583

Franks PJ, Adams MA, Amthor JS, Barbour MM, Berry JA, Ellsworth DS et al (2013) Sensitivity of plants to changing atmospheric $\mathrm{CO}_{2}$ concentration: from the geological past to the next century. New Phytol 197:1077-1094

Fu L, Xu Y, Xu Z, Wu B, Zhao D (2020) Tree water-use efficiency and growth dynamics in response to climatic and $\mathrm{T}$ environmental changes in a temperate forest in Beijing, China. Environ Int 134

Gessler A, Ferrio JP, Hommel R, Treydte K, Werner RA, Monson RK (2014) Stable isotopes in tree rings: towards a mechanistic understanding of isotope fractionation and mixing processes from the leaves to the wood. Tree Physiol 34:796-818

Giorgi F, Lionello P (2008) Climate change projections for the Mediterranean region. Glob Planet Change 63:90-104

González de Andrés E, Camarero JJ, Blanco JA, Bosco Imbert J, Lo YH, Sangüesa Barreda G, Castillo FJ (2018) Tree-to-tree competition in mixed European beech-Scots pine forests has different impacts on growth and water-use efficiency depending on site conditions. J Ecol 106:59-75

González-Muñoz N, Linares JC, Castro-Díez P, Sass-Klaassen U (2015) Contrasting secondary growth and water-use efficiency patterns in native and exotic trees co-occurring in inner Spain riparian forests. Forest Syst 24(1):e017 (10 pages)

Granda E, Rossatto DR, Camarero JJ, Voltas J, Valladares F (2014) Growth and carbon isotopes of Mediterranean trees reveal contrasting responses to increased carbon dioxide and drought. Oecologia 174:307-317

Grassi G, House J, Dentener F, Federici S, den Elzen M, Penman J (2017) The key role of forests in meeting climate targets 
requires science for credible mitigation. Nat Clim Change 7:220-226

Guerrieri R, Belmecheri S, Ollinger SV, Asbjornsen H, Jennings K, Xiao J, Stocker BD, Martin M, Hollinger DH, Bracho-Garrillo R, Clark K, Dore S, Kolb T, Munger JW, Novick K, Richardson AD (2019) Disentangling the role of photosynthesis and stomatal conductance on rising forest water-use efficiency. PNAS 116(34):16909-16914. https://doi.org/10.1073/pnas.1905912116

Harlow BA, Marshall JD, Robinson AP (2005) A multispecies comparison of $\delta^{13} \mathrm{C}$ from whole wood, extractive free wood and holocellulose. Tree Physiol 26:767-774

Harmon ME, Marks B (2002) Effects of silvicultural treatments on carbon stores in forest stands. Can J Forest Res 32:863-877

Holmes RL (1983) Computer-assisted quality control in tree-ring dating and measurement. Tree Ring Bull 43:69-78

Huang JG, Bergeron Y, Denneler B, Berninger F, Tardif J (2007) Response of forest trees to increased atmospheric $\mathrm{CO}_{2}$. Crit Rev Plant Sci 26:265-283

IUNCC-The World Conservation Union and Foundation (2004) Afforestation and reforestation for climate change mitigation: potentials for Pan-European Action. Warsaw, July 2004

Jackson RB, Jobbagy EG, Avissar R, Roy SB, Barrett DJ et al (2005) Trading water for carbon with biological carbon sequestration. Science 310:1944-1947

Jarvis AJ, Davies WJ (1998) The coupled response of stomatal conductance to photosynthesis and transpiration. J Exp Bot 49:399-406

Keeling CD, Piper SC, Bacastow RB, Wahlen M, Whorf TP, Heimann $\mathrm{M}$, Meijer HA (2001) Exchanges of atmospheric $\mathrm{CO}_{2}$ and ${ }^{13} \mathrm{CO}_{2}$ with the terrestrial biosphere and oceans from 1978 to 2000. I. Global aspects, SIO Reference Series, No. 01-06. Scripps Institution of Oceanography, San Diego ( 88 pages)

Kobziar L, Stephens SL (2006) The effects of fuels treatments on soil carbon respiration in a Sierra Nevada pine plantation. Agric Forest Meteorol 141:161-178

Krankina ON, Harmon ME (2006) Forest management strategies for carbon storage. In: Cloughesy M (ed) Forests, carbon, and climate change: a synthesis of science findings. Oregon Forest Resources Institute, Portland, Oregon, pp 79-92

Kwak JH, Lim SS, Lee KS, Viet HD, Matsushima M, Lee KH, Jung K, Kim HY, Lee SM, Chang SX, Choi WJ (2016) Temperature and air pollution affected tree ring $\delta^{13} \mathrm{C}$ and water-use efficiency of pine and oak trees under rising $\mathrm{CO}_{2}$ in a humid temperate forest. Chem Geol 420:127-213

Lauteri M, Scartazza M, Guido MC, Brugnoli E (1997) Genetic variation in photosynthetic capacity, carbon isotope discrimination and mesophyll conductance in provenances of Castanea sativa adapted to different environments. Funct Ecol 11:675-683

Lenth RV (2016) Least-squares means: the R package lsmeans. J Stat Softw 69(1):1-33

Leonardi S, Gentilesca T, Guerrieri R, Ripullone F, Magnani F, Mencuccini M, Noije TV, Borghetti M (2012) Assessing the effects of nitrogen deposition and climate on carbon isotope discrimination and intrinsic water-use efficiency of angiosperm and conifer trees under rising $\mathrm{CO}_{2}$ conditions. Glob Change Biol 18:2925-2944

Lévesque M, Siegwolf R, Saurer M, Eilmann B, Rigling A (2014) Increased water-use efficiency does not lead to enhanced tree growth under xeric and mesic conditions. New Phytol 203:94-109

Loader NJ, Walsh RPD, Robertson I, Bidin K, Ong RC, Reynolds G, McCarroll D, Gagen M, Young GHF (2011) Recent trends in the intrinsic water-use efficiency of ringless rainforest trees in Borneo. Philos Trans R Soc B Biol Sci 366:3330-3339

Marchand W, Girardin MP, Hartmann H, Depardieu C, Isabel N, Gauthier S, Boucher É, Bergeron Y (2020) Strong overestimation of water-use efficiency responses to rising $\mathrm{CO}_{2}$ in tree-ring studies. Glob Change Biol 6(8):4538-4558
Marshall JD, Monserud RA (1996) Homeostatic gas-exchange parameters inferred from ${ }^{13} \mathrm{C} /{ }^{12} \mathrm{C}$ in tree rings of conifers. Oecologia 105:13-21

McCarrol D, Loader NJ (2004) Stable isotopes in tree rings. Quat Sci Rev 23:771-801

McDowell N, Pockman WT, Allen CD, Breshears DD, Cobb N, Kolb T, Plaut J, Sperry J, West A, Williams DG, Yepez EA (2008) Mechanisms of plant survival and mortality during drought: why do some plants survive while others succumb to drought? New Phytol 178:719-739

Nakagawa S, Schielzeth H (2013) A general and simple method for obtaining R2 from generalized linear mixed-effects models. Methods Ecol Evol 4(2):133-142

Norby RJ, Zak DR (2011) Ecological lessons from free-air $\mathrm{CO}_{2}$ enrichment (FACE) experiments. Annu Rev Ecol Evolut Syst 42(1):181-203

Peñuelas J, Azcón-Bieto J (1999) Changes in leaf $\delta^{13} \mathrm{C}$ of herbarium plant species during the last 3 centuries of $\mathrm{CO}_{2}$ increase. Plant Cell Environ 15:485-489

Peñuelas J, Hunt JM, Ogaya R, Jump AS (2008) Twentieth century changes of tree ring $\delta^{13} \mathrm{C}$ at the southern range-edge of Fagus sylvatica: increasing water-use efficiency does not avoid the growth decline induced by warming at low altitudes. Glob Change Biol 14:1076-1088

Peñuelas J, Canadell JG, Ogaya R (2011) Increased water-use efficiency during the 20th century did not translate into enhanced tree growth. Glob Ecol Biogeogr 20(4):597-608

Picon C, Guehl JM, Aussenac G (1996) Growth dynamics, transpiration and water-use efficiency in Quercus robur plants submitted to elevated $\mathrm{CO}_{2}$ and drought. Ann For Sci 53:431-446

R Core Team (2020) R: A language and environment for statistical computing. R Foundation for Statistical Computing, Vienna, Austria. https://www.R-project.org

Rasheed F, Dreyer E, Le Thiec D, Zafar Z, Delagrange S (2019) Tree aging does not affect the ranking for water use efficiency recorded from $\delta^{13} \mathrm{C}$ in three Populus deltoides $\times$ P. nigra genotypes. iForest Biogeosci For 12(3):272-278

Reyer C, Guericke M, Ibisch PL (2009) Climate change mitigation via afforestation, reforestation and deforestation avoidance: and what about adaptation to environmental change? New For 38:5-34

Riechelmann DFC, Maus M, Dindorf W, Konter O, Schone BR, Esper I (2016) Comparison of $\delta^{13} \mathrm{C}$ and $\delta^{18} \mathrm{O}$ from cellulose, whole wood, and resin-free whole wood from an old high elevation Pinus uncinata in the Spanish central Pyrenees. Isot Environ Health Stud. https://doi.org/10.1080/10256016.2016.1161622

Ripullone F, Lauteri M, Grassi G, Amato M, Borghetti M (2004) Variation in nitrogen supply changes the water use efficiency of Pseudotsuga menziesii and Populus x euroamericana; a comparison of three different approaches to determine water-use efficiency. Tree Physiol 24:671-679

Ripullone F, Borghetti M, Raddi S, Vicinelli E, Baraldi R, Guerrieri MR, Nolè A, Magnani F (2009a) Physiological and structural changes in response to altered precipitation regimes in a Mediterranean macchia ecosystem. Trees 23(4):823-834

Ripullone F, Guerrieri MR, Saurer M, Siegwolf R, Jäggi M, Guarini $\mathrm{R}$, Magnani F (2009b) Testing a dual isotope model to track carbon and water gas exchanges in a Mediterranean forest. iForest 2:59-66

Saurer M, Siegwolf RTW, Schweingruber FH (2004) Carbon isotope discrimination indicates improving water-use efficiency of trees in northern Eurasia over the last 100 years. Glob Change Biol 10:2109-2120

Saurer M, Spahni R, Frank DC, Joos F, Leuenberger M, Loader NJ, McCarroll D, Gagen M, Poulter B, Siegwolf RTW, Andreu-Hayles L, Boettger T, Liñán ID, Fairchild IJ, Friedrich M, Gutierrez E, Haupt M, Hilasvuori E, Heinrich I, Helle G, Grudd H, Jalkanen 
R, Levanič T, Linderholm HW, Robertson I, Sonninen E, Treydte K, Waterhouse JS, Woodley EJ, Wynn PM, Young GHF (2014) Spatial variability and temporal trends in water-use efficiency of European forests. Glob Change Biol 20(12):3700-3712

Seibt U, Rajabi A, Griffiths H, Berry JA (2008) Carbon isotopes and water use efficiency: sense and sensitivity. Oecologia 155:441-454

Silva LCR, Anand M (2013) Probing for the influence of atmospheric $\mathrm{CO}_{2}$ and climate change on forest ecosystems across biomes. Glob Ecol Biogeogr 22(1):83-92

Smith J, van den Driessche R (1992) Root growth and water use efficiency of Douglas-fir (Pseudotsuga menziesii (Mirb.) Franco) and lodgepole pine (Pinus contorta Dougl.) seedlings. Tree Physiol 11:401-410

Teskey R, Wertin T, Bauweraerts I, Ameye M, Mcguire MA, Steppe K (2015) Responses of tree species to heat waves and extreme heat events. Plant Cell Environ 38:1699-1712

Tognetti R, Lombardi F, Lasserre B, Cherubini P, Marchetti M (2014) Tree-ring stable isotopes reveal twentieth century increases in water-use efficiency of Fagus sylvatica and Nothofagus spp. in Italian and Chilean mountains. PLoS ONE 9:e113136. https:// doi.org/10.1371/journal.pone.0113136

Unkovich M, Blott K, Knight A, Mock I, Rab A, Portelli M (2003) Water use, competition, and crop production in low rainfall, alley farming systems of south-eastern Australia. Aust J Agric Res 54:751-762

Walker AP, De Kauwe MG, Bastos A, Belmecheri S, Georgiou K, Keeling R, McMahon SM, Medlyn BE, Moore DJP, Norby RJ,
Zaehle S, Anderson-Teixeira KJ, Battipaglia G, Brienen RJW, Cabugao KJ, Cailleret M, Campbell E, Canadell J, Ciais P, Craig ME, Ellsworth D, Farquhar G, Fatichi S, Fisher JB, Frank D, Graven H, Gu L, Haverd V, Heilman K, Heimann M, Hungate BA, Iversen CM, Joos F, Jiang M, Keenan TF, Knauer J, Körner C, Leshyk VO, Leuzinger S, Liu Y, MacBean N, Malhi Y, McVicar T, Penuelas J, Pongratz J, Powell AS, Riutta T, Sabot MEB, Schleucher J, Sitch S, Smith WK, Sulman B, Taylor B, Terrer C, Torn MS, Treseder K, Trugman AT, Trumbore SE, van Mantgem PJ, Voelker SL, Whelan ME, Zuidema PA (2020) Integrating the evidence for a terrestrial carbon sink caused by increasing atmospheric $\mathrm{CO}_{2}$. New Phytol. https://doi.org/10.1111/nph.16866

Wang W, Jiali L, Hongju D, Chenhui W, Huimei W, Yujie F, Xingyuan $H$ (2017) Ranking thirteen tree species based on their impact on soil physiochemical properties, soil fertility, and carbon sequestration in Northeastern China. For Ecol Manag 404:214-229

Zuur A, Ieno EN, Walker N, Saveliev AA, Smith GM (2009) Mixed effects models and extensions in ecology with R. Springer Science $\&$ Business Media, New York

Publisher's Note Springer Nature remains neutral with regard to jurisdictional claims in published maps and institutional affiliations. 